\title{
Genetic aspects of age dynamics of a natural Picea abies (L.) Karst. population in the Białowieża Primeval Forest, Poland
}

\author{
A. Wojnicka-Półtorak • W. Prus-Głowacki • K. Celiński • \\ A. Korczyk
}

Received: 11 May 2012/ Accepted: 25 April 2013/Published online: 3 May 2013

(C) The Author(s) 2013. This article is published with open access at Springerlink.com

\begin{abstract}
We studied temporal changes in the genetic structure and diversity of a naturally regenerated Picea abies (L.) Karst. (Norway spruce) population in the Białowieża Primeval Forest, Poland. The analysis included five age classes of trees: newly germinating seedlings (in laboratory conditions), seedlings up to 3 years old, young trees 4-10 years old, middle-aged trees 11-100 years old, and trees older than 100 years. We conducted genetic analyses of 26 allozyme loci using dormant buds from 405 individuals and 100 embryos. The results showed that the naturally regenerating Norway spruce population is genetically heterogeneous across the studied age classes. As determined by Chi squared tests, there were statistically significant differences in frequencies of alleles and genotypes as well as Wright's index values (F) among the five age classes. The level of genetic differentiation (pairwise $\mathrm{F}_{\mathrm{ST}}=0.5-2.3 \%$ ) among the age class groups was equal to levels previously determined for various populations of this species. The Ewens-Watterson test for neutrality showed that one or two loci across different age classes of Norway spruce were affected by the selection process. The distinctiveness of embryo and seedling classes was confirmed by the number of detected alleles, the number of private alleles, the level of observed heterozygosity, and Wright's index value. The results obtained in the present study indicate there are interesting dynamics of adaptation processes occurring in the natural age-diverse population of Norway spruce in the Białowieża Primeval Forest.
\end{abstract}

Keywords Age dynamics - Genetic differentiation - Primeval population - Picea abies . Natural regeneration

\footnotetext{
A. Wojnicka-Półtorak $(\bowtie) \cdot$ W. Prus-Głowacki · K. Celiński Department of Genetics, Faculty of Biology, Institute of Experimental Biology, Adam Mickiewicz University, Umultowska 89, 61-614 Poznań, Poland e-mail: olawp@amu.edu.pl
}

\section{A. Korczyk}

Branch Faculty of Forest in Hajnówka, Bialystok University of Technology, Piłsudskiego 8, 17-200 Hajnówka, Poland e-mail: a.korczyk@pb.edu.pl 


\section{Introduction}

Norway spruce (Picea abies (L.) Karst.) is one of the most widely distributed tree species in Europe, and it is an important component of boreal and mixed coniferous broad-leaved forests. Because of its widespread use in forestry and its importance in the ecosystem, there is much interest in its ecological requirements and its genetic structure at the population level (Ravazzi 2001). The genetic structure of populations of $P$. abies has been investigated in a number of studies (Lagercrantz and Ryman 1990; Maghuly et al. 2006; Scotti et al. 2006; Vendramin et al. 2000); however, most of those studies were conducted in plantation forests. Also, little is known about the differentiation of the genetic structure of spruce populations at various stages of development (Leonardi et al. 1996; Prus-Głowacki and Godzik 1995). There have been few studies on the temporal genetic variations in conifer populations, and most have compared the genetic structure only between the seedling populations and their respective adult tree populations (Roberds and Conkle 1984; Shaw and Allard 1982; Yazdani et al. 1985).

Unfortunately, this approach can not reveal the dynamics of processes at play at different stages of the developing population. However, this can be studied in old tree stands in Białowieża Primeval Forest, a stretch of primeval forest in central-eastern Poland. These stands have preserved their primary gene pools and, therefore, are an important point of reference for European forests that have been heavily modified by human actions, especially those of cultivated species such as P. abies and Pinus sylvestris L. According to Korczyk (1994, 1995), old tree stands in the Białowieża Primeval Forest are of immense value to science and forest management for several reasons; they are relics of native wild populations that have arisen via the process of natural selection, their genotypes developed in the pre-industrial era and were not subject to human selection, and they are extremely adaptable, which has allowed them to live to such an old age.

Norway spruce, $P$. abies, is one of the main species in tree stands in the Białowieża Primeval Forest, a natural ancient woodland covering an area of 150 thousand hectares and straddling the border between Poland and Belarus. The western part of the forest, located in Poland, occupies an area of 62.5 thousand hectares. The most widely valued section of the forest in terms of natural biodiversity and wildlife is formally protected as the Białowieża National Park, which was established in 1921. In 1977, UNESCO recognized the park as one of Poland's four Biosphere Reserves and in 1979 it was added to the World Heritage List.

The Białowieża Primeval Forest represents the last remaining parts of primeval forests that once extended across the European Plain. The forest consists of primary ecosystem types that have not been affected by human activity for a long time. The forest areas have been subject to protection at least since the beginning of the 15 th century, when they were hunting grounds of the kings of Poland. The Polish royal protection policy during that period strictly limited forest resource management, thereby helping to maintain natural values of the forests better so than in other temperate zone forest regions in Europe (Więcko 1984). Until the year 1888, artificial reforestation was not applied. The forest regenerated naturally, therefore all the old trees above 150 years of age are relics of native populations resulting from the process of natural selection (Korczyk 2008). A distinctive feature of Białowieża's old-growth forests is their complex structure that includes a variety of species and tree stands of different ages. The tree stands protected in the Białowieża National Park's strict reserve have maintained attributes of ancient virgin forests that once covered the central regions of Europe (Faliński 1968). The Białowieża Primeval Forest provides a remarkable opportunity to investigate genetic processes involved in natural regeneration of tree stands in a formed forest ecosystem. 


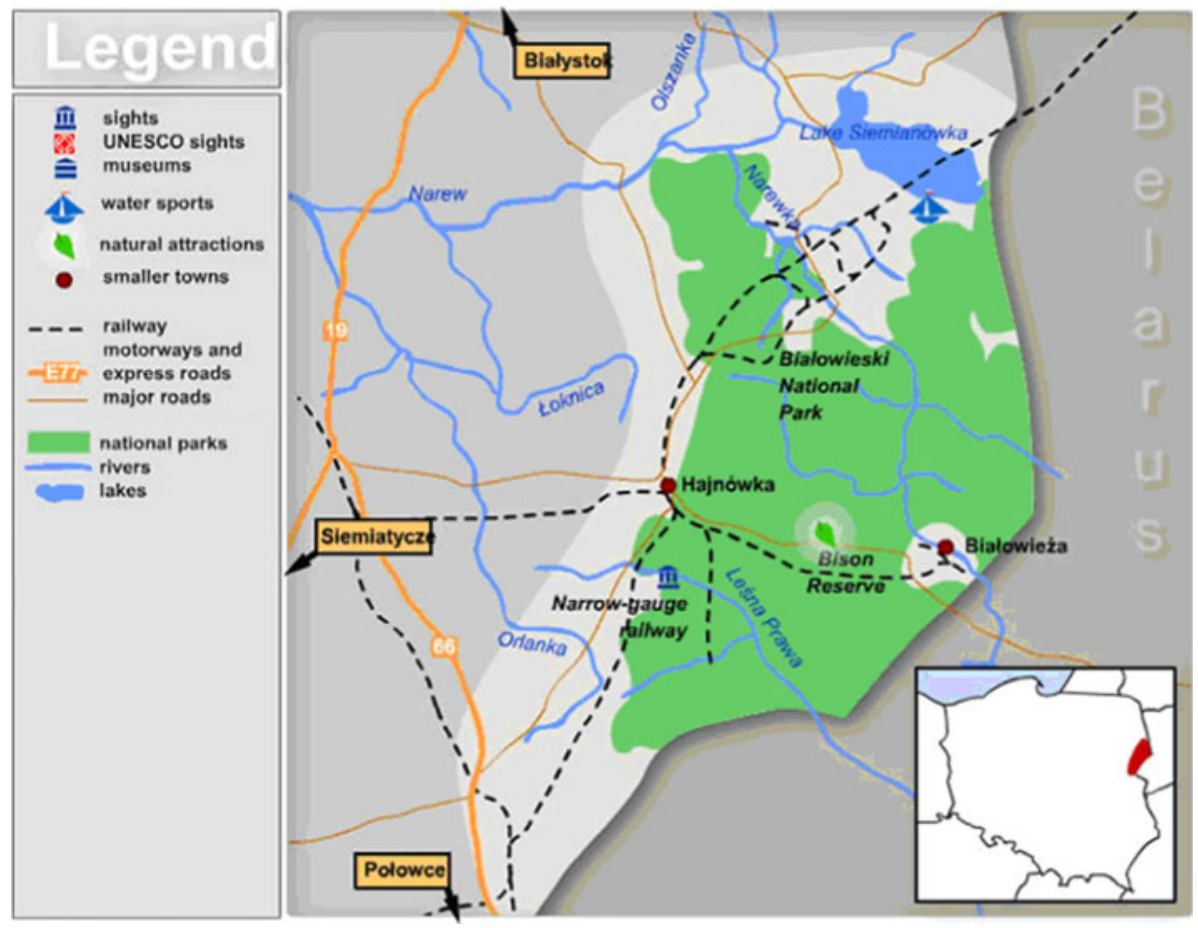

Fig. 1 Location of the Białowieża Primeval Forest in Poland (map obtained from http://holidays.staypoland. com/bialowieza-forest.aspx; modified)

The aim of the present study was to estimate the genetic structure and diversity of a naturally regenerated $P$. abies population in the Białowieża Primeval Forest with respect to its demographic structure, using allozyme markers.

\section{Materials and methods}

Study site and sampling

The study area was located in the Białowieża Primeval Forest in central eastern Poland, in the Hajnówka Forest District (Fig. 1). Studies were conducted in a tree stand in a naturally regenerated Norway spruce (P. abies) population in compartment 631A, subdivision " $\mathrm{b}$ " (area of 9.9 ha). The only treatments applied in this compartment during the 1960s were removing trees toppled over and infested by bark beetles (Korczyk 1994).

For the purposes of genetic analyses, we collected dormant buds from 505 individuals representing five age classes of Norway spruce: E-embryos (100 individuals), S-seedlings up to 3 years old (100 individuals), Y-young trees 4-10 years old (104 individuals), M-middle-aged 11-100 years old (107 individuals), $\mathrm{O}$-older than 100 years (94 individuals). The age of each individual was estimated by their diameter at breast height and by counting their growth rings. The distance between the sampled trees was 10-200 $\mathrm{m}$ for the $\mathrm{O}$ and partly $\mathrm{M}$ class. For the remaining trees the distance was $0.5-20 \mathrm{~m}$. For the E class, embryos were obtained from the seeds of a few cones collected from 50 seed trees of $\mathrm{M}$ 
and $\mathrm{O}$ age classes. Seeds were mixed together and formed a pooled sample which germinated in laboratory conditions.

Isoenzyme analysis

Crude enzyme extracts were prepared from 2 to 3 winter buds from a single tree (or one seedling germinated from a seed in laboratory conditions for the embryo class). The buds were ground with extraction buffer $(0.5 \mathrm{M}$ Tris- $\mathrm{HCl} \mathrm{pH} 7,5$ containing EDTA, $\mathrm{KCl}$, $\mathrm{MgCl}_{2}$, PVP, and Triton). For electrophoresis, two buffer systems were used: A) Triscitrate $\mathrm{pH} 7.0$ (electrode buffer)/Tris-histidine $\mathrm{pH} 7.0$ (gel buffer); B) LiOH-borate $\mathrm{pH} 8.5$ (electrode buffer)/Tris-citrate-LiOH-borate $\mathrm{pH} 8.5$ (gel buffer) (Cheliak and Pitel 1984; Conkle et al. 1982). The following 13 enzyme systems encoded by 26 loci were used for analyses: fluorescent esterase (EC 3.1.1.1. FEST; 3 loci), glutamate dehydrogenase (EC 1.4.1.2. GDH; 1 locus), glutamate-oxaloacetate transaminase (EC 2.6.1.1. GOT; 3 loci), isocitrate dehydrogenase (EC 1.1.1.42 IDH; 2 loci), malate dehydrogenase (EC 1.1.1.37. $\mathrm{MDH} ; 3$ loci), shikimate dehydrogenase (EC 1.1.1.25 SHDH; 2 loci), phosphoglucomutase (EC 2.7.5.1. PGM; 2 loci), 6-phosphogluconate dehydrogenase 6PGD; 2 loci), glucose-6phosphate dehydrogense (EC 1.1.1.49 G6PD; 2 loci), NADH-dependent dehydrogenase (EC 1.6.5.3 NDH; 2 loci), phosphoglucose isomerase (EC 5.3.1.9. PGI; 1 locus), diaphorase (EC 1.6.4.3. DIA; 2 loci), and malic enzyme (EC 1.1.1.40 ME; 1 locus).

Data analysis

The data were analyzed using PopGene (Yeh et al. 1997), GenAlEx 6.5 population genetics software (Peakall and Smouse 2012) and Statistica 10 software. Genetic variability was described by the total number of alleles, number of private alleles, percentage of polymorphic loci (95\% criterion), frequency of alleles and genotypes (tested by the Chi squared test for statistical significance of differences among age groups), expected $\left(\mathrm{H}_{\mathrm{e}}\right)$ and observed $\left(\mathrm{H}_{\mathrm{o}}\right)$ heterozygosity. We calculated the Wright's fixation index $\mathrm{F}$ for all the polymorphic loci in each age group as a relative measure of deviations from the Hardy-Weinberg equilibrium (HWE) expected for random mating (Jain and Workman 1967; Nei and Roychoudhury 1974). The Chi squared test was applied to test for HWE. The statistical means were tested using U MannWhitney ANOVA tests to verify the significance of the differences. The genetic distance between pairs of the subpopulations was computed according to Nei (1972). The unweighted pair group method with arithmetic mean cluster analysis was used to generate a dendrogram of the relationships among the 5 age classes, supported by the bootstrap analysis using tools for population genetic analysis (TFPGA; Miller 1997). The algorithm used for the bootstrap analysis followed Felsenstein's (1985) procedure. The level of genetic differentiation between the subpopulations was estimated using F-statistics calculated using Nei's formula (1977) (1,000 permutations). To detect possible effects of selection, the Ewens-Watterson test for neutrality (1,000 permutations) (Manly 1985) was performed for each locus.

\section{Results}

Allele frequencies

We analyzed 26 loci in five age classes of Norway spruce, and determined the presence of between 58 alleles (in the seedling class and the 4-10-year-old trees class) and 67 alleles 
Table 1 Sample sizes $(\mathrm{N})$, percent of polymorphic loci $(\% \mathrm{P})$, number of alleles $(\mathrm{Na})$, number of private alleles (PA), expected (He) and observed (Ho) heterozygosity, and Fixation index $(\mathrm{F})$ in age classes

\begin{tabular}{llllllll}
\hline & $\mathrm{N}$ & $\mathrm{P}(\%)$ & $\mathrm{Na}$ & $\mathrm{PA}$ & $\mathrm{He}$ & Ho & $\mathrm{F}$ \\
\hline $\mathrm{E}$ & 100 & 69 & 67 & 6 & 0.110 & 0.081 & 0.217 \\
$\mathrm{~S}$ & 100 & 77 & 58 & 2 & 0.123 & 0.120 & 0.020 \\
$\mathrm{Y}$ & 104 & 73 & 58 & 0 & 0.119 & 0.105 & 0.055 \\
$\mathrm{M}$ & 107 & 69 & 59 & 1 & 0.118 & 0.108 & 0.069 \\
$\mathrm{O}$ & 94 & 85 & 59 & 0 & 0.112 & 0.107 & 0.012 \\
Pooled sample & 505 & 96 & 75 & 0 & 0.117 & 0.103 & 0.063 \\
\hline
\end{tabular}

$E$ embryos, $S$ seedlings, $Y$ young trees 4-10, $M$ middle-aged 11-100, $O$ older than 100 years

(in the embryo class) (Table 1). The percentage of polymorphic loci ranged from $69 \%$ in the $\mathrm{E}$ and $\mathrm{M}$ class to $85 \%$ in the "O" class (Table 1). For the whole population (pooled sample) it was $96 \%$. Loci G6PD A and B, DIA B, FEST A and B, GDH, GOT C, IDH A, NDH A and B, PGI, PGM, and SHDH B were polymorphic in all the age-class groups. Private alleles were identified in the embryo class ( 6 private alleles), the seedling class ( 2 private alleles), and the middle-aged tree class (1 private allele) (Table 1). Allele frequencies for all loci in the various age classes as well as for the pooled sample are listed in Table 2. A Chi squared test showed statistically significant differences in frequencies of some alleles and genotypes among different age classes of Norway spruce (Table 3). The frequencies of alleles at 6PGD B1 and 2, GDH 1, and G6PD A3 and 4, differentiated the E and $\mathrm{S}$ classes from the other classes. The $\mathrm{O}$ class had the highest frequency of alleles at 6PGD B3 and the lowest frequency of alleles at FEST A3. The frequency of alleles at GDH 1 differed significantly among all the age groups. The frequency of alleles at PGI 2 distinguished class $\mathrm{M}$ from class $\mathrm{Y}$ and class $\mathrm{O}$. The Ewens-Watterson test for neutrality (Manly 1985) showed that one or two loci across different age classes of Norway spruce were affected by the selection process: class E-MDH C and SHDH B; class S-GOT C and IDH B; class $\mathrm{Y}-$ GOT $\mathrm{C}$; and class $\mathrm{O}-$ FEST A. These statistics were calculated using 1,000 simulated samples. The frequencies of some genotypes of the six enzyme loci (6PGD B, G6PD A, GDH, GOT C, NDH A and B) differentiated E and S classes from other classes, while that at the locus PGI distinguished the M class from other classes.

\section{Genetic differentiation}

The observed heterozygosity $\left(\mathrm{H}_{\mathrm{o}}\right)$ (mean for the 26 studied loci) was lowest in the E class (0.081, $24 \%$ lower than that in older age classes) and highest in the $\mathrm{S}$ class $(0.120)$. The $\mathrm{H}_{\mathrm{o}}$ values were comparable among the classes Y (0.105), M (0.108), and O (0.107) (Table 1). For the whole Norway spruce population (pooled sample) observed heterozygosity was rather low (0.103).

Wright's F index (mean calculated for 26 loci) indicated a statistically significant excess of homozygotes in the embryos class (0.217). $U$ Mann-Whitney tests showed statistically significant differences in Wright's F index among class E S $(p<0.02)$, and class $\mathrm{O}$ $(p<0.04)$. The Wright's $\mathrm{F}$ index for $\mathrm{Y}$ and $\mathrm{M}$ tree classes was 0.055 and 0.069 , respectively (Table 1). The $\mathrm{S}$ and $\mathrm{O}$ classes were closest to the (HWE) (0.022 and 0.012, respectively). Table 4 summarizes significant (as determined by Chi squared test) deviations from the Hardy-Weinberg equilibrium for different loci in the studied spruce age 
Table 2 Allele frequencies by age classes of $P$. abies

\begin{tabular}{|c|c|c|c|c|c|c|c|}
\hline Locus & Allele & $\mathrm{E}$ & $\mathrm{S}$ & $\mathrm{Y}$ & M & $\mathrm{O}$ & Pooled sample \\
\hline \multirow[t]{3}{*}{ 6PGD A } & 1 & 0.021 & 0.000 & 0.000 & 0.000 & 0.000 & 0.002 \\
\hline & 2 & 0.971 & 0.978 & 0.995 & 1.000 & 0.995 & 0.990 \\
\hline & 3 & 0.007 & 0.022 & 0.005 & 0.000 & 0.005 & 0.007 \\
\hline \multirow[t]{4}{*}{ 6PGD B } & 1 & 0.927 & 0.636 & 0.825 & 0.782 & 0.830 & 0.814 \\
\hline & 2 & 0.068 & 0.364 & 0.165 & 0.197 & 0.121 & 0.168 \\
\hline & 3 & 0.005 & 0.000 & 0.010 & 0.007 & 0.049 & 0.015 \\
\hline & 5 & 0.000 & 0.000 & 0.000 & 0.014 & 0.000 & 0.002 \\
\hline DIA A & 2 & 1.000 & 1.000 & 1.000 & 1.000 & 1.000 & 1.000 \\
\hline \multirow[t]{3}{*}{ DIA B } & 1 & 0.954 & 0.965 & 0.976 & 0.939 & 0.968 & 0.960 \\
\hline & 2 & 0.018 & 0.000 & 0.019 & 0.033 & 0.011 & 0.016 \\
\hline & 3 & 0.028 & 0.035 & 0.005 & 0.028 & 0.021 & 0.024 \\
\hline \multirow[t]{3}{*}{ FEST A } & 1 & 0.018 & 0.035 & 0.011 & 0.020 & 0.005 & 0.019 \\
\hline & 2 & 0.939 & 0.953 & 0.989 & 0.965 & 0.989 & 0.967 \\
\hline & 3 & 0.043 & 0.012 & 0.000 & 0.015 & 0.005 & 0.014 \\
\hline \multirow[t]{2}{*}{ FEST B } & 1 & 0.975 & 0.985 & 0.955 & 0.912 & 0.951 & 0.957 \\
\hline & 2 & 0.025 & 0.015 & 0.045 & 0.088 & 0.049 & 0.043 \\
\hline \multirow[t]{3}{*}{ FEST C } & 1 & 0.000 & 0.000 & 0.030 & 0.005 & 0.000 & 0.007 \\
\hline & 2 & 0.993 & 0.985 & 0.965 & 0.976 & 1.000 & 0.983 \\
\hline & 3 & 0.007 & 0.015 & 0.005 & 0.019 & 0.000 & 0.010 \\
\hline \multirow[t]{4}{*}{ G6PD A } & 1 & 0.008 & 0.008 & 0.015 & 0.025 & 0.022 & 0.015 \\
\hline & 2 & 0.823 & 0.900 & 0.814 & 0.850 & 0.841 & 0.838 \\
\hline & 3 & 0.059 & 0.015 & 0.005 & 0.000 & 0.016 & 0.023 \\
\hline & 4 & 0.110 & 0.077 & 0.167 & 0.125 & 0.121 & 0.124 \\
\hline \multirow[t]{2}{*}{ G6PD B } & 2 & 1.000 & 1.000 & 1.000 & 0.995 & 0.995 & 0.998 \\
\hline & 3 & 0.000 & 0.000 & 0.000 & 0.005 & 0.005 & 0.002 \\
\hline \multirow[t]{3}{*}{ GDH } & 1 & 0.031 & 0.133 & 0.124 & 0.019 & 0.064 & 0.074 \\
\hline & 2 & 0.900 & 0.791 & 0.832 & 0.893 & 0.862 & 0.854 \\
\hline & 3 & 0.069 & 0.077 & 0.045 & 0.089 & 0.074 & 0.072 \\
\hline \multirow[t]{2}{*}{ GOT A } & 1 & 1.000 & 1.000 & 1.000 & 0.995 & 0.995 & 0.998 \\
\hline & 2 & 0.000 & 0.000 & 0.000 & 0.005 & 0.005 & 0.002 \\
\hline \multirow[t]{2}{*}{ GOT B } & 1 & 0.989 & 0.990 & 0.990 & 1.000 & 1.000 & 0.994 \\
\hline & 2 & 0.011 & 0.010 & 0.010 & 0.000 & 0.000 & 0.006 \\
\hline \multirow[t]{3}{*}{ GOT C } & 1 & 0.535 & 0.480 & 0.471 & 0.593 & 0.590 & 0.536 \\
\hline & 2 & 0.461 & 0.520 & 0.529 & 0.407 & 0.410 & 0.463 \\
\hline & 3 & 0.004 & 0.000 & 0.000 & 0.000 & 0.000 & 0.001 \\
\hline \multirow[t]{3}{*}{ IDH A } & 2 & 0.016 & 0.023 & 0.029 & 0.042 & 0.021 & 0.028 \\
\hline & 3 & 0.973 & 0.953 & 0.966 & 0.949 & 0.973 & 0.961 \\
\hline & 4 & 0.011 & 0.023 & 0.005 & 0.009 & 0.005 & 0.010 \\
\hline \multirow[t]{3}{*}{ IDH B } & 1 & 0.000 & 0.005 & 0.000 & 0.000 & 0.000 & 0.001 \\
\hline & 2 & 1.000 & 0.990 & 1.000 & 1.000 & 0.989 & 0.996 \\
\hline & 3 & 0.000 & 0.005 & 0.000 & 0.000 & 0.011 & 0.003 \\
\hline
\end{tabular}


Table 2 continued

\begin{tabular}{|c|c|c|c|c|c|c|c|}
\hline Locus & Allele & $\mathrm{E}$ & $\mathrm{S}$ & $\mathrm{Y}$ & M & $\mathrm{O}$ & Pooled sample \\
\hline \multirow[t]{3}{*}{$\mathrm{MDH} \mathrm{A}$} & 1 & 0.000 & 0.007 & 0.000 & 0.000 & 0.000 & 0.001 \\
\hline & 2 & 1.000 & 0.993 & 0.995 & 0.995 & 0.984 & 0.994 \\
\hline & 3 & 0.000 & 0.000 & 0.005 & 0.005 & 0.016 & 0.005 \\
\hline \multirow[t]{2}{*}{ MDH B } & 2 & 0.996 & 1.000 & 1.000 & 0.995 & 0.995 & 0.998 \\
\hline & 3 & 0.004 & 0.000 & 0.000 & 0.005 & 0.005 & 0.002 \\
\hline \multirow[t]{3}{*}{ MDH C } & 2 & 0.004 & 0.000 & 0.000 & 0.000 & 0.000 & 0.001 \\
\hline & 4 & 0.992 & 1.000 & 0.985 & 1.000 & 0.995 & 0.994 \\
\hline & 5 & 0.004 & 0.000 & 0.015 & 0.000 & 0.005 & 0.005 \\
\hline \multirow[t]{2}{*}{ ME } & 2 & 1.000 & 0.993 & 1.000 & 1.000 & 0.995 & 0.998 \\
\hline & 3 & 0.000 & 0.007 & 0.000 & 0.000 & 0.005 & 0.002 \\
\hline \multirow[t]{2}{*}{ NDH A } & 1 & 0.032 & 0.065 & 0.039 & 0.037 & 0.032 & 0.039 \\
\hline & 2 & 0.968 & 0.935 & 0.961 & 0.963 & 0.968 & 0.961 \\
\hline \multirow[t]{4}{*}{ NDH B } & 1 & 0.004 & 0.014 & 0.000 & 0.005 & 0.000 & 0.003 \\
\hline & 2 & 0.482 & 0.576 & 0.578 & 0.505 & 0.539 & 0.519 \\
\hline & 3 & 0.504 & 0.410 & 0.422 & 0.491 & 0.461 & 0.475 \\
\hline & 4 & 0.011 & 0.000 & 0.000 & 0.000 & 0.000 & 0.003 \\
\hline \multirow[t]{4}{*}{ PGI } & 1 & 0.008 & 0.005 & 0.024 & 0.010 & 0.000 & 0.009 \\
\hline & 2 & 0.438 & 0.440 & 0.476 & 0.340 & 0.486 & 0.426 \\
\hline & 3 & 0.539 & 0.535 & 0.495 & 0.626 & 0.500 & 0.548 \\
\hline & 4 & 0.016 & 0.020 & 0.005 & 0.024 & 0.014 & 0.016 \\
\hline \multirow[t]{3}{*}{ PGM A } & 1 & 0.007 & 0.005 & 0.000 & 0.005 & 0.005 & 0.004 \\
\hline & 2 & 0.975 & 0.985 & 0.986 & 0.981 & 0.963 & 0.979 \\
\hline & 3 & 0.018 & 0.010 & 0.014 & 0.014 & 0.032 & 0.017 \\
\hline \multirow[t]{2}{*}{ PGM B } & 2 & 0.996 & 1.000 & 1.000 & 1.000 & 0.995 & 0.999 \\
\hline & 3 & 0.004 & 0.000 & 0.000 & 0.000 & 0.005 & 0.001 \\
\hline \multirow[t]{3}{*}{ SHDH A } & 1 & 0.985 & 0.995 & 0.995 & 1.000 & 1.000 & 0.996 \\
\hline & 2 & 0.010 & 0.005 & 0.005 & 0.000 & 0.000 & 0.003 \\
\hline & 3 & 0.005 & 0.000 & 0.000 & 0.000 & 0.000 & 0.001 \\
\hline \multirow[t]{7}{*}{ SHDH B } & 1 & 0.938 & 0.945 & 0.875 & 0.916 & 0.947 & 0.928 \\
\hline & 2 & 0.012 & 0.000 & 0.038 & 0.028 & 0.005 & 0.015 \\
\hline & 3 & 0.035 & 0.035 & 0.058 & 0.033 & 0.037 & 0.038 \\
\hline & 4 & 0.004 & 0.005 & 0.014 & 0.009 & 0.000 & 0.006 \\
\hline & 5 & 0.004 & 0.000 & 0.005 & 0.000 & 0.000 & 0.002 \\
\hline & 6 & 0.004 & 0.000 & 0.000 & 0.000 & 0.000 & 0.001 \\
\hline & 7 & 0.004 & 0.015 & 0.010 & 0.014 & 0.011 & 0.011 \\
\hline
\end{tabular}

See Table 1

classes. The majority showed an excess of homozygotes, most prominently in the E class. Particular enzyme loci demonstrated a high differentiation of Wright's index (F) values among the studied age classes. These were the same loci that showed significantly different frequencies of alleles and genotypes among particular age classes (Tables 3 and 4). The whole population of $P$. abies is close to the HWE ( $\mathrm{F}=0.063)$, but loci FEST A, B, C, G6PD A, GDH and MDH B exhibit significant $(p \leq 0.001)$ deviations from the HWE. 
Table 3 Significant Chi Square tests for differences in allele and genotype frequencies (in brackets) between age classes

\begin{tabular}{|c|c|c|c|c|}
\hline Locus & Allel/Genotype & Age class & & Chi square \\
\hline \multirow[t]{4}{*}{ 6PGD B } & \multirow[t]{4}{*}{1} & $S(0.636)$ & $\mathrm{E}(0.936)$ & 13.19 \\
\hline & & $S(0.636)$ & $\mathrm{Y}(0.825)$ & 4.13 \\
\hline & & $S(0.636)$ & $\mathrm{O}(0.830)$ & 4.1 \\
\hline & & E (0.936) & $\mathrm{M}(0.782)$ & 4.4 \\
\hline 6PGD B & 2 & E (0.059) & $S(0.364)$ & 60.78 \\
\hline \multirow[t]{8}{*}{ 6PGD B } & \multirow[t]{8}{*}{3} & E (0.059) & $\mathrm{Y}(0.165)$ & 33.70 \\
\hline & & E (0.059) & $\mathrm{M}(0.197)$ & 33.99 \\
\hline & & E (0.059) & $\mathrm{O}(0.121)$ & 23.31 \\
\hline & & $S(0.364)$ & $\mathrm{Y}(0.165)$ & 12.61 \\
\hline & & $S(0.364)$ & M (0.197) & 6.77 \\
\hline & & $\mathrm{S}(0.364)$ & $\mathrm{O}(0.121)$ & 19.10 \\
\hline & & $\mathrm{O}(0.049)$ & $\mathrm{Y}(0.010)$ & 3.92 \\
\hline & & $\mathrm{O}(0.049)$ & $\mathrm{E}(0.005)$ & 5.45 \\
\hline \multirow[t]{4}{*}{ 6PGD B } & \multirow[t]{4}{*}{1} & E (0.990) & $S(0.455)$ & 16.58 \\
\hline & & E (0.990) & M (0.676) & 5.09 \\
\hline & & $\mathrm{S}(0.455)$ & $\mathrm{Y}(0.738)$ & 5.69 \\
\hline & & $\mathrm{S}(0.455)$ & $\mathrm{O}(0.736)$ & 5.23 \\
\hline \multirow[t]{6}{*}{ 6PGD B } & \multirow[t]{6}{*}{1} & $\mathrm{E}(0.063)$ & $S(0.364)$ & 30.36 \\
\hline & & $\mathrm{E}(0.063)$ & $\mathrm{Y}(0.165)$ & 14.89 \\
\hline & & $\mathrm{E}(0.063)$ & $\mathrm{M}(0.211)$ & 16.22 \\
\hline & & $\mathrm{E}(0.063)$ & $\mathrm{O}(0.143)$ & 11.79 \\
\hline & & $S(0.364)$ & $\mathrm{Y}(0.165)$ & 6.30 \\
\hline & & $\mathrm{S}(0.364)$ & $\mathrm{O}(0.143)$ & 7.55 \\
\hline \multirow[t]{2}{*}{ 6PGD B } & \multirow[t]{2}{*}{2} & $\mathrm{~S}(0.182)$ & $\mathrm{E}(0.018)$ & 13.25 \\
\hline & & $\mathrm{S}(0.182)$ & $\mathrm{O}(0.022)$ & 8.34 \\
\hline \multirow[t]{4}{*}{ G6PD A } & 2 & $\mathrm{E}(0.102)$ & $\mathrm{Y}(0.010)$ & 7.17 \\
\hline & 2 & $\mathrm{E}(0.102)$ & $\mathrm{M}(0.000)$ & 9.70 \\
\hline & 2 & E (0.110) & $\mathrm{Y}(0.235)$ & 5.18 \\
\hline & 4 & E (0.110) & $\mathrm{O}(0.220)$ & 3.96 \\
\hline \multirow[t]{4}{*}{ GDH } & \multirow[t]{4}{*}{1} & E (0.046) & $S(0.184)$ & 9.38 \\
\hline & & E (0.046) & $\mathrm{Y}(0.149)$ & 6.22 \\
\hline & & $\mathrm{S}(0.184)$ & $\mathrm{M}(0.037)$ & 9.92 \\
\hline & & Y (0.149) & $\mathrm{M}(0.037)$ & 5.77 \\
\hline \multirow[t]{2}{*}{ GOT C } & 1 & $\mathrm{~S}(0.222)$ & $\mathrm{M}(0.383)$ & 4.41 \\
\hline & 2 & Y $(0.330)$ & $\mathrm{O}(0.149)$ & 6.75 \\
\hline \multirow[t]{3}{*}{ NDH A } & \multirow[t]{3}{*}{1} & E (0.007) & $\mathrm{S}(0.129)$ & 10.59 \\
\hline & & E (0.007) & $\mathrm{Y}(0.078)$ & 5.56 \\
\hline & & E (0.007) & $\mathrm{M}(0.075)$ & 5.34 \\
\hline
\end{tabular}

The mean $\mathrm{F}_{\mathrm{ST}}$ value for 26 analyzed loci was 0.016 (probability $0.001 ; 999$ permutations). The pairwise $\mathrm{F}_{\mathrm{ST}}$ value varied among the different age classes, from 0.001 to 0.023 (Table 5). 
Table 3 continued

See Table 1

\begin{tabular}{lllllc}
\hline Locus & Allel/Genotype & Age class & & Chi square \\
\hline NDH B & 2 & 2 & E (0.414) & M (0.262) & 4.25 \\
& 2 & 3 & E (0.121) & S (0.486) & 23.20 \\
& & & E (0.121) & Y (0.471) & 24.92 \\
& & & E (0.121) & M (0.477) & 4.25 \\
& \multirow{2}{*}{3} & & E (0.121) & O (0.456) & 22.25 \\
& & & E (0.436) & S (0.167) & 12.74 \\
& & & E (0.436) & M (0.252) & 6.04 \\
& & & E (0.436) & O (0.233) & 6.04 \\
PGI & 2 & M (0.126) & Y (0.252) & 4.33 \\
& & & M (0.126) & O (0.268) & 4.42 \\
\hline
\end{tabular}

The greatest genetic distance of 0.006 (Nei 1972) was between the embryos and the seedlings groups. A dendrogram constructed from genetic distance data showed that the seedling class was the most genetically distinct from the other classes $(\mathrm{DN}=0.015$; Fig. 2).

Six of the 26 analysed loci have intermediate allele frequencies (6PGD B, G6PD A, GDH, GOT C, NDH B and PGI), which differ among the age classes. We have found drastically lower (by $85 \%$ on average) observed heterozygosity in the embryos class in locus 6PGD B, compared to the remaining age classes. The total for these six loci $\mathrm{F}_{\mathrm{ST}}$ (0.019) was comparable to those using all 26 loci. The strongest significant genetic differentiation among the age classes was found in locus 6PGD B $F_{\mathrm{ST}}=0.063$ (Table 6). Nei's (1972) genetic distances among the particular age classes, calculated for these six loci, were higher (0.007-0.038) than for the 26 loci (0.001-0.006).

\section{Discussion}

The results obtained in this study show that the naturally regenerating $P$. abies population in the Białowieża Primeval Forest is genetically heterogeneous across the studied age classes. The level of genetic differentiation $\left(\mathrm{F}_{\mathrm{ST}}\right)$ among age classes in the studied population of spruce trees $(0.1-2.3 \%$ for 26 loci; $0.7-3.8 \%$ for 6 loci) tended to be comparable to levels previously determined for various populations of coniferous species $\left(\mathrm{F}_{\mathrm{ST}}=1.7 \%\right.$, Goncharenko et. al. 1995; $\mathrm{F}_{\mathrm{ST}}=6 \%$ Cengel et al. 2012; $\mathrm{G}_{\mathrm{ST}}=5.2 \%$, Lagercrantz and Ryman 1990; $\mathrm{G}_{\mathrm{ST}}=7 \%$, Prus-Głowacki and Bernard 1994). This shows that the genetic structure of the studied age classes of $P$. abies is diverse, as confirmed by the Ewens-Watterson test for neutrality, and that it can be affected by selection processes that exist at various levels of population development. As Charlesworth et al. (1997) pointed out, selection affecting any locus tends to increase differentiation within the population, and very high $\mathrm{F}_{\mathrm{ST}}$ values may be found at this locus. Chung et al. (2003) reported weak but statistically significant genetic differentiation among age classes $\left(\mathrm{F}_{\mathrm{ST}}=0,008\right)$ of Camellia japonica $\mathrm{L}$. Schnabel and Hamrick (1990) studied the temporal genetic structure of Gleditsia triacanthos L., and found significant differences among eight age classes at 9 out of 27 loci examined. The opposite tendency was reported by Linhart et al. (1981) for ponderosa pine and by Knowles and Grant (1985) for lodgepole pine. In 
Table 4 Summary of Chi square tests for Hardy-Weinberg equilibrium ( $\mathrm{F}$ values in brackets) in particular loci for age classes
See table 1

Key $* p<0.05, * * p<0.01$, $* * * p<0.001$

\begin{tabular}{|c|c|c|c|c|c|}
\hline Locus & $\mathrm{E}$ & $\mathrm{S}$ & $\mathrm{Y}$ & M & $\mathrm{O}$ \\
\hline $\begin{array}{c}\text { 6PGD } \\
\text { B }\end{array}$ & $(0.646)^{* * *}$ & & $(0.367) * *$ & $(0.275)^{*}$ & $(0.179)^{* * *}$ \\
\hline $\begin{array}{c}\text { FEST } \\
\text { A }\end{array}$ & $(0.302)^{* * *}$ & $(0.48) * * *$ & $(-0.011)^{* *}$ & $(0.267)^{* * * *}$ & \\
\hline $\begin{array}{c}\text { FEST } \\
\text { B }\end{array}$ & & & & $(0.291)^{* *}$ & \\
\hline $\begin{array}{c}\text { FEST } \\
\mathrm{C}\end{array}$ & $(1.0)^{* * *}$ & & $(0.263)^{*}$ & $(0.388)^{* * * *}$ & \\
\hline $\begin{array}{c}\text { G6PD } \\
\text { A }\end{array}$ & $(0.263)^{* * *}$ & & & & \\
\hline GDH & & & $(0.183)^{*}$ & & $(0.056)^{*}$ \\
\hline $\begin{array}{c}\mathrm{NDH} \\
\mathrm{A}\end{array}$ & $(0.795)^{* * *}$ & & & & \\
\hline $\begin{array}{c}\mathrm{NDH} \\
\mathrm{B}\end{array}$ & $(0.741)^{* * *}$ & & & & \\
\hline $\begin{array}{c}\text { GOT } \\
\text { C }\end{array}$ & & & $(0.201)^{*}$ & & \\
\hline
\end{tabular}

those studies, the age classes did not differ markedly from one another in their genetic characteristics.

Among all the age classes analyzed, the embryo class showed the highest genetic richness, expressed by the greatest number of alleles at 26 allozyme loci and number of private alleles. On the other hand, this class showed the lowest observed heterozygosity and the greatest excess of homozygotes as compared to the HWE. The statistically significant (U Mann-Whitney test) difference in Wright's index values also confirms the differences between the $\mathrm{E}$ and $\mathrm{S}$ classes and the $\mathrm{O}$ class (oldest trees). In conifers, low heterozygosity and a high excess of homozygosity at the early ontogenic stages is a relatively common phenomenon resulting from the mixed mating system. Inbreeding is commonly attributed to self-pollination and, in the case of the family structure of forest stands, to crossing between close relatives (Politov et al. 2006). Korshikov et al. (2007) reported an excess of homozygous genotypes in the genetic structure of the embryo population of Abies alba Mill., Pinus pallasiana Lamb. and Pinus sylvestris. A heterozygote surplus both in embryos $(\mathrm{F}=-0.066)$ and maternal plants $(\mathrm{F}=-0.074)$ was reported for Picea glauca (Moench) Voss in Ontario, Canada (Cheliak et al. 1985). In a population of this species in Alberta, Canada, heterozygote deficiency was observed in adults $(\mathrm{F}=0.039)$ and in embryos from two different seed crop years $(\mathrm{F}=0.029-0.031)$ (King et al. 1984). Krzakowa and Korczyk (1995) studied a population of Norway spruce with individuals aged from 35 to 240 years old in the Białowieża Primeval Forest, and reported a slight excess of homozygotes (mean of 11 allozyme loci $F=0.062$ ) and a higher mean observed heterozygosity value $\left(\mathrm{H}_{\mathrm{o}}=0.237\right)$ than those determined in the present study $\left(\mathrm{H}_{\mathrm{o}}=0.081-0.120\right)$.

We observed a high number of alleles at the studied loci, and the greatest number of private alleles was observed in the embryo class. These are typical features indicating that pollination probably involved trees from outside the tree stand investigated in this study. The distinctiveness of the genetic structure in the embryo class is also marked by significant differences in the frequency of some alleles, e.g. a low frequency of allele 2 at locus 
Table 5 Pairwise $\mathrm{F}_{\mathrm{ST}}$ values among age classes

See table 1

$\mathrm{F}_{\text {st }}$ values below the diagonal. Probability P based on 999 permutations is shown above diagonal

\begin{tabular}{llllll}
\hline & $\mathrm{E}$ & $\mathrm{S}$ & $\mathrm{Y}$ & $\mathrm{M}$ & $\mathrm{O}$ \\
\hline $\mathrm{E}$ & - & 0.001 & 0.002 & 0.002 & 0.039 \\
$\mathrm{~S}$ & 0.023 & - & 0.002 & 0.001 & 0.001 \\
$\mathrm{Y}$ & 0.011 & 0.009 & - & 0.002 & 0.111 \\
$\mathrm{M}$ & 0.008 & 0.012 & 0.009 & - & 0.062 \\
$\mathrm{O}$ & 0.007 & 0.013 & 0.005 & 0.005 & - \\
\hline
\end{tabular}

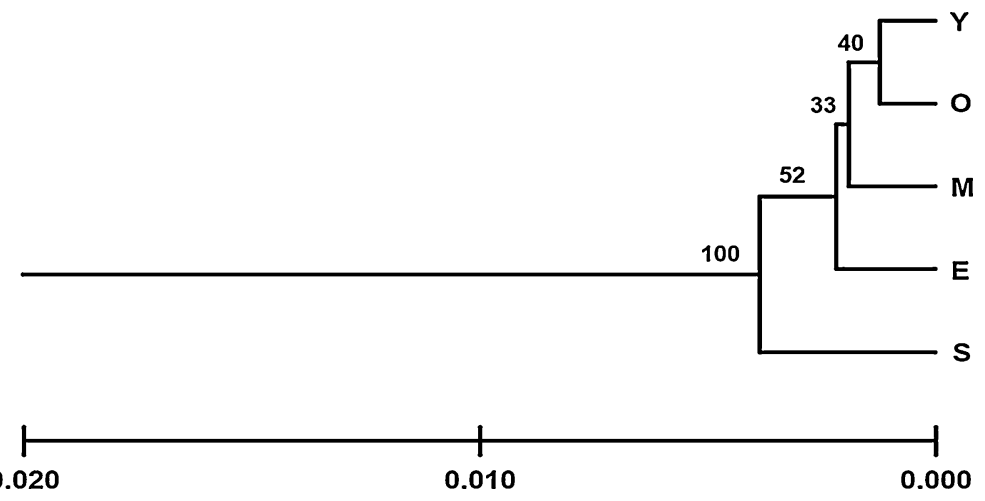

Fig. 2 Dendrogram based on genetic distance (Nei 1972) between the age classes: $E$ embryos, Sseedlings, $Y$ young trees 4-10, $M$ middle-aged 11-100, $O$ older than 100 year. Values at the nodes indicate bootstrap values from 1,000 replication

Table 6 Summary of F-statistics (by Nei's formula 1977) among the five age classes

\begin{tabular}{llllllll}
\hline & 6PGD B & G6PD A & GDH & GOT C & NDH B & PGI & Total \\
\hline Fis & 0.285 & 0.117 & 0.049 & 0.038 & 0.175 & 0.083 & 0.120 \\
Fst & 0.063 & 0.010 & 0.015 & 0.011 & 0.014 & 0.010 & 0.019 \\
Prob & 0.001 & 0.124 & 0.020 & 0.035 & 0.027 & 0.060 & 0.001 \\
\hline
\end{tabular}

$\mathrm{F}_{\mathrm{IS}}$-the inbreeding coefficient within individuals relative to the population; $\mathrm{F}_{\mathrm{ST}}$-genetic differentiation among populations, probability $P$ of $F_{\mathrm{ST}}$ value based on 999 permutations

6PGD B. Konnert (1991) reported that the locus differentiated in a highly significant manner in three age groups of $P$. abies (8-10-year-old trees, mature trees, and embryos). In that study, the author established that selection promoted one allele at locus 6PGD B in younger age classes (up to 10 years old), but acted against it in older age groups. In our study, we did not detect a clear trend in this direction, but we observed that allele 6PGD B2 showed the highest frequency in the seedling group (0-3-year-old trees) and a more stable frequency in the oldest age groups. The locus 6PGD B significantly differentiated among the age classes in the Norway spruce population in this study. Prus-Głowacki (1982) studied variation among age classes of Scots pine, and found significant differences in the frequency of some allozymes among various age groups. That finding, the author claimed, can be interpreted as evidence that selection within a population affects specific phenotypes, which results in the selection of individual alleles. In the present study high values for the $\mathrm{F}_{\mathrm{ST}}$ index and observed heterozygosity in 6PGD B locus provide evidence that this 
locus is the most diversifying between the embryos and seedlings groups and the rest of age classes.

The seedling class showed considerably fewer alleles, and only two private alleles. Furthermore, the seedling group had the highest observed heterozygosity of all the age classes investigated, whereas the fixation index F indicated a status close to the HardyWeinberg equilibrium, similarly to the older trees. This shows that the elimination of homozygotes in the studied population of Norway spruce occurs at a very early stage of population development; that is, up to 3 years old. Muona et al. (1987) reported that selection against inbred individuals in artificially regenerated Scots pine stands began at approximately 3 years of age. In naturally regenerating Scots pine stands, the elimination of homozygous individuals occurred among 10-20-year-old trees (Yazdani et al. 1985).

Three age classes (4-10 years old; 11-100 years old, and >100 years old) showed relatively similar levels of genetic variation in terms of the number of alleles, observed heterozygosity, small genetic distance and lower pairwise $\mathrm{F}_{\mathrm{ST}}$ values. This proves that the genetic variation in the studied population of $P$. abies is less diverse in older ages than in seedlings, confirming the observations of Prus-Głowacki (1982) on the different age classes of Scots pine. A trend of lower heterozygosity in a group of older trees, accompanied by an higher frequency of the predominant allele, was also observed in an isolated population of Pinus sylvestris (Korshikov and Mudrik, 2006), and in Pinus pallasiana (Korshikov et al., 2011). Staszak et al. (2007) noted $34 \%$ higher observed heterozygosity in younger trees than in older trees in Pinus Jeffreyi Balf. The oldest age class of P. abies ( $>100$ years) in the Białowieża Primeval Forest was the closest to the HWE and had the highest frequency of polymorphic loci $(85 \%)$. The above genetic characteristics of the oldage group have also been identified in populations of other coniferous species (Shea 1990; Tigersted et al. 1982; Konnert 1991). Some authors, however, have reported high heterozygosity in older-age groups of coniferous populations (Yazdani et al.1985; Starova et al.1990).

The results obtained in the present study suggest that there may be interesting dynamics of adaptation processes occurring in the natural age-diverse population of $P$. abies in the Białowieża Primeval Forest. At the first stage, there may be intensive selection against homozygotic individuals. At the second stage genetic structure of the population may adjust optimally to specific conditions, up to the state which can be defined as stabilization observed in the older age classes. The population oscillates around the HWE and the trees may reach an old age in part because of this genetic structure. Similar trends in age dynamics of genetic variation have been reported in an isolated population of Pinus sylvestris in Donbass, Ukraine (Korshikov and Mudrik, 2006). Our study has demonstrated clear pattern of genetic differentiation in relation to demographic genetic substructuring within the examined Norway spruce population.

By studying naturally regenerating tree stands in the Białowieża Forest, we can monitor processes involved in the development of a population structure without human interference. This is very important for $P$. abies, which is intensively cultivated in Europe (Chmura 2012). As emphasized by Gömöry et al. (2010), trees are keystone species for the majority of natural or seminatural terrestrial ecosystems, and are the foundation for many associated communities. Diversity is the main prerequisite determining the ability of a living system, whether it is a population, a community, or an ecosystem, to adapt to environmental changes. Considering the above, the Białowieża Primeval Forest needs to be protected at the genetic level as well as at the ecosystem level (Dering et al. 2011). Studies on the genetic variability of populations in which individuals are at different stages of development are important for developing strategies for conservation of intraspecific 
diversity (Korshikov and Mudrik 2006). As pointed out by Altukhov et al. (1996), the analysis of age dynamics of the genetic population structure may be crucial for understanding mechanisms that maintain the genetic diversity during individual development and the evolution of populations. The results presented here may prove useful in harvesting and sampling procedures for research, gene conservation, reforestation and forest management. There is a need to integrate the knowledge from genetic, demographic and ecological approaches to species conservation to be able to formulate management strategies which may have the great impact on the genetic potential of our forests.

Acknowledgments This work was funded by the Ministry of Science and Higher Education in Poland, grant: 3P04F 00725.

Open Access This article is distributed under the terms of the Creative Commons Attribution License which permits any use, distribution, and reproduction in any medium, provided the original author(s) and the source are credited.

\section{References}

Althukov YuP, Korokchkin LI, Rychkov YG (1996) Hereditary biochemical diversity in evolution and development. Genetica (Moscow) 32:1256-1275

Cengel B, Tayanc Y, Kandemir G, Velioglu E, Alan M, Kaya Z (2012) Magnitude and efficiency of genetic diversity captured from seed stands of Pinus nigra (Arnold) subsp. Pallasiana in established seed orchards and plantations. New Forest 43:303-317

Charlesworth B, Nordborg M, Charlesworth D (1997) The effects of local selection, balanced polymorphism and background selection on equilibrium patterns of genetic diversity in subdivided populations. Genet Res 70:155-174

Cheliak WM, Pitel JA (1984) Techniques for starch gel electrophoresis of enzymes from forest tree species. Petawawa National Institute

Cheliak WM, Pitel JA, Murray G (1985) Population structure and mating system of white spruce. Can J For Res 15:301-308

Chmura D (2012) Phenology differs among Norway spruce populations in relation to local variation in altitude of maternal stands in the Beskidy Mountains. New Forest 32:2-31

Chung MY, Epperson BK, Chung MG (2003) Genetic structure of age classes in Camellia japonica (Theaceae). Evolution 57(1):62-73

Conkle MT, Hodgskiss PD, Nunnally LB,Hunter SC (1982) Starch gel electrophoresis of conifer seeds: a laboratory manual. USDA for Serv Tech Rep PSW-64

Dering M, Misiorny A, Lewandowski A, Korczyk A (2011) Genetic and historical studies on the origin of Norway spruce in Białowieża Primeval Forest in Poland. Eur J Forest Res 131(2):381-387

Faliński JB (1968) National Park in Białowieża. PWN Warsaw (in Polish)

Felsenstein J (1985) Confidence limits on phylogenies: an approach using the bootstrap. Evolution 39:783-791

Gömöry D, Longauer R, Paule L, Krajmerova D, Schmidtova J (2010) Across-species patterns of genetic variation in forest trees of Central Europe. Biodivers Conserv 19:2025-2038

Goncharenko GG, Zadeika IV, Birgelis JJ (1995) Genetic structure, diversity and differentiation of Norway spruce (Picea abies (L.) Karst.) in natural populations in Latvia. Forest Ecol and Management $72: 31-38$

Jain SK, Workman PL (1967) Generalized F-statistics and the theory of inbreeding and selection. Nature 214:674-678

King JN, Dancik BP, Dhir NK (1984) Genetic structure and mating system of white spruce (Picea glauca) in a seed production area. Can J For Res 14:639-643

Knowles P, Grant M (1985) Genetic variation of lodgepole pine over time and microgeographical space. Can J For Res 63:722-727

Konnert VM (1991) Vergleich der genetischen struktur verschiedener generationen zweier naturlich verjungter fichtenbestande des Schwarzwaldes. Silvae Genetica 40(2):60-65

Korczyk AF (1994) Identification of genetic diversity. Part I. Demographic structure of natural populations of Pinus sylvestris L. and Picea abies Karst. in the Białowieża Forest. Report GEF 05/21655 Pol part 3.04 
Korczyk AF (1995) Protection and conservation of gene resources of forest trees in the Białowieża Forest. In: Paschalis P, Rykowski K, Zajączkowski St (eds) Protection of forest ecosystems biodiversity of Białowieża Primeval Forest. Pol Forest Biodiversity Protection Project, Warsaw, pp 95-102

Korczyk AF (2008) The stock-taking of old trees and threatened trees species in the Białowieża primeval forest. Forest Research Papers 69(2):117-126

Korshikov II, Mudrik EA (2006) Age dynamics of genetic variation in an isolated population of Chalk pine Pinus sylvestris var. Cretacea Kalenicz. Ex. Kom. From Donbass. Plant Genetics 42(5):532-538

Korshikov II, Pirko NN, Mudrik EA, Pirko YAV (2007) Maintenance of genetic structure in progenies of marginal mountainous and steppe populations of three species of Pinaceae Lindl Family in Ukraine. Silvae Genetica 56:1-10

Korshikov II, Mudrik EA, Krasnoshtan OV, Velikoridko TI, Kalafat LA, Podgornyi DI (2011) Age dynamics of population gene pool of the Crimean pine (Pinus pallasiana D. Don) in Crimea. Tsitol Genet 45:41-47

Krzakowa M, Korczyk AF (1995) Enzymatic diversity of Nowary spruce Picea abies (L.) Karst. From the Białowieża Forest. In: Protection of forest ecosystems biodiversity of Białowieża Primeval Forest. Edited by Paschalis P, Rykowski K, Zajączkowski S Warsaw : pp 67-80

Lagercrantz U, Ryman N (1990) Genetic structure of Norway spruce (Picea abies): concordance of morphological and allozymic variation. Evolution 44:38-53

Leonardi S, Raddi S, Borghetti M (1996) Spatial autocorrelation of allozyme traits in a Norway spruce (Picea abies) population. Can J For Res 26:63-71

Linhart YB, Mitton JB, Sturgeon KB, Davis ML (1981) Genetic variation in space and time in a population of ponderosa pine. Heredity 46:407-426

Maghuly F, Pinsker W, Praznik W, Fluch S (2006) Genetic diversity in managed subpopulations of Norway spruce (Picea abies (L.) Karst.). For Ecol Manage 222:266-271

Manly BFJ (1985) The statistics of natural selection on animal populations. Chapman and Hall London: pp 272-282

Miller MP (1997) TFPGA Version 1.3. A Windows program for the analysis of allozyme and molecular population genetic data. Depart. of Biological Sci. Northern Arizona University. pp 30

Muona O, Yazdani R, Rudin D (1987) Genetic change between life stages in Pinus sylvestris: allozyme variation in seeds and planted seedlings. Silvae Genetica 36(1):39-42

Nei M (1972) Genetic distance between populations. Am Nat 106:283-292

Nei M (1977) F-statistics and analysis of gene diversity in subdivided populations. Ann Hum Genet 41:225-233

Nei M, Roychoudhury AK (1974) Sampling variances of heterozygosity and genetic distance. Genetics 76:379-390

Peakall R, Smouse PE (2012) GenAlEx 6.5: genetic analysis in excel. population genetic software for teaching and research-un update. Bioinformatics 28(19):2537-2539

Politov DV, Belokon MM, Belokon YS (2006) Dymanics of allozyme heterozygosity in Siberian Dwarf pine Pinus pumila (Pall.) Regel populations of the Russian Far East: comparison of embryos and maternal plants. Plant Genetics 42(10):1127-1136

Prus-Głowacki W (1982) Studies on genetic variation in age classes of naturally regenerating population of Pinus sylestris L. UAM w Poznaniu, Seria Biologia 24 (in Polish)

Prus-Głowacki W, Bernard E (1994) Allozyme variation in populations of Pinus sylvestris L. from 1912 provenance trial in Pulawy (Poland). Silvae Genetica 43:132-138

Prus-Głowacki W, Godzik S (1995) Genetic structure of Picea abies trees tolerant and sensitive to industrial pollution. Silvae Genetica 44:2-3

Ravazzi C (2001) Late quaternary history of spruce in southern Europe. Rev of Paleobot. and Polynology 120:131-177

Roberds JH, Conkle MT (1984) Genetic structure in loblolly pine stands: allozyme variation in parents and progeny. For Sci 30(2):319-329

Schnabel A, Hamrick JL (1990) Organization of genetic diversity within and among populations of Gleditsia differentiation. Ann For Sci 63:485-491

Scotti I, Paglia G, Magni F, Morgante M (2006) Population genetics of Norway spruce (Picea abies Karst) at regional scale: sensitivity of different microsatellite motif classes in detecting differentiation. Ann For Sci 63:485-491

Shaw DV, Allard RW (1982) Isoenzyme heterozygosity in adult and open pollinated embryo samples of douglas-fir. Silva Fennica 16(2):115-121

Shea KL (1990) Genetic variation between and within populations of Engelmann spruce and subalpine fir. Genome 33:1-8 
Starova NV, Yanabaev YuA, Yumadilov NKh et al (1990) Genetic variability of Pinus sylvestris age classes. Genetica (Moscow) 26(3):498-505

Staszak J, Grulke NE, Marrett MJ, Prus-Głowacki W (2007) Isozyme markers asscotiated with $\mathrm{O}_{3}$ tolerance indicate shift in genetic structure of ponderosa and Jeffrey pine in Sequoia National Park, California. Env Pol 149:366-375

Tigersted PMA, Rudin D, Niemela T, Tammisola (1982) Competition and neighbouring effect in a naturally regeneration populations of Scots pine. Silva Fenn 16:122-129

Vendramin G, Anzidei M, Madaghiele A, Sperisen C, Bucci G (2000) Chloroplast microsatellite analysis reveals the presence of population subdivision in Norway spruce (Picea abies K.). Genome 43:68-78

Więcko E (1984) Puszcza Białowieska. PWN, Warszawa

Yazdani R, Muona O, Rudin D, Szmidt AE (1985) Genetic structure of a seed tree stand and naturally regenerated plants of Pinus sylvestris L. Forest Sci 31(2):430-436

Yeh FC, Yang R-C, Boyle T, Ye Z-H, Mao JX (1997) POPGENE: the user-friendly shareware for population genetic analysis Molecular Biology and Biotechnology Centre. University of Alberta, Canada 